\title{
Urban growth squeezes agriculture
}

\section{Albert G. Medvitz}

A century ago, the state was populated by 1 million Californians about the same number who now attend the Rose Bowl Parade every Jan. 1.

Today's state population is 33 times greater. The Department of Finance recently reported a $1.8 \%$ increase for the year ending July 1997 - 574,000 more people. The numbers signaled a resurgence of net migration and continuing high rate of natural increase. The same figures showed that all but four counties grew, and Monterey and San Benito counties tied for the state's highest growth, at $4.9 \%$.

Rapid growth is a century-long trend in California (fig. 1). Since the time of the Gold Rush, California's

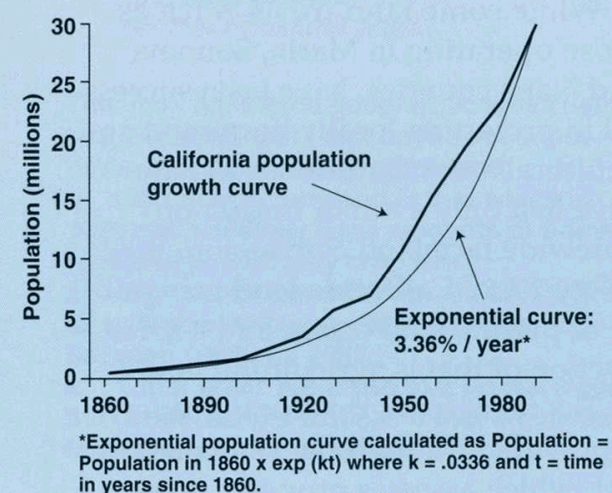

Fig. 1. California population growth, 1860-1990.

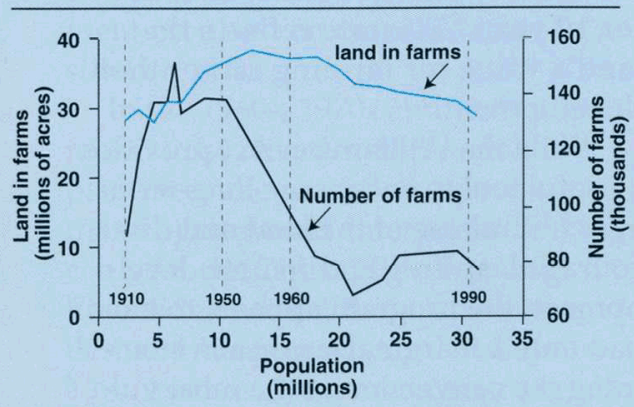

Fig. 2. Number of farms and land in farms versus population, 1910 to 1992. Source: U.S. Census Bureau, Censuses of Agriculture. average yearly growth has exceeded $3.36 \%$ per year. Even when growth slowed during the recession of the early 1990s, California's fastest growing counties topped the growth rate of most countries in the world (table 1).

In recent decades, urban growth has led to farmland losses and changing economics for a number of farms. According to U.S. Bureau of the Census figures, the state lost close to 9 million acres of farmland between 1950 and 1993, a decline of almost 25\%, from about 38 million to 29 million acres. As California's population continues to grow, so will urban land. By 2100, if current land-use patterns don't change, urban land in California could occupy one-third of the state - more area than is currently occupied by agriculture.

\section{The reverse of a trend}

For the first half of this century, farms and farmland increased along with California's population growth. But after 1950, the trend reversed. As population increased further, farmland declined (fig. 2). Urban populations moved into the agricultural midcoastal valleys of Ventura and Monterey and San Luis Obispo and the fertile valleys east, north and south of San Francisco, dramatically transforming the landscape. Aerial photographs (see p. 9) show the consequences of this trend for the Santa Clara Valley.

Nevertheless, the volume of agricultural production has continued to increase to the present. Farmland losses were countered after World War II by massive irrigation projects such as the Central Valley Project, which allowed the expansion of intensive irrigated agriculture into otherwise arid grazing lands in the Southern San Joaquin Valley. Growers continued to adopt new technologies and crops, and further diversified, expanding from 200 commodities at the end of
World War II to 350 crop and livestock commodities by 1996 .

Despite increasing production, markets changed such that the value of the state's agricultural production experienced an extended decline after 1975, if figures are adjusted for inflation. In constant 1992 dollars, the 1975 value of production was $\$ 25$ billion and the 1993 value of production was $\$ 18$ billion. Production value has shown an upward trend in the past 5 years.

\section{What lies ahead?}

More recently, population has spread over the Tehachapis south of Bakersfield and over the coastal ranges into the fertile Central Valley. This time agriculture has nowhere to go. The children of dairy farmers who sold their San Bernadino operations and resettled in the Central Valley don't have the same options their parents had, because additional dairy land is not readily available in the state. Relo-

TABLE 1. Five-year average of population growth rates of selected countries, California and selected California counties, 1990-1995

$\begin{array}{llll}\text { Imperial } & 4.4^{\star} & \text { Orange } & 2.0 \\ \text { Israel } & 3.8 \dagger & \text { Bangladesh } & 2.0 \\ \text { Madera } & 3.5 & \text { India } & 1.9 \\ \text { Peru } & 3.3 & \text { San Bernadino } & 1.9 \\ \text { Saudi Arabia } & 3.0 & \text { Haiti } & 1.8 \\ \text { Nigeria } & 2.9 & \text { Brazil } & 1.6 \\ \text { Kenya } & 2.8 & \text { California } & 1.4 \\ \text { Afghanistan } & 2.8 & \text { Santa Clara } & 1.3 \\ \text { Riverside } & 2.8 & \text { Argentina } & 1.2 \\ \text { Zimbabwe } & 2.6 & \text { China } & 1.1 \\ \text { Kern } & 2.3 & \text { Los Angeles } & 1.0 \\ \text { South Africa } & 2.3 & \text { United States } & 1.0 \\ \text { Fresno } & 2.3 & \text { Switzerland } & 1.0 \\ \text { Vietnam } & 2.2 & \text { France } & 0.5 \\ \text { Tulare } & 2.2 & \text { Japan } & 0.3 \\ \text { Ecuador } & 2.1 & \text { Great Britain } & 0.3 \\ \text { Stanislaus } & 2.0 & \text { Russia } & 0.1 \\ \text { Mexico } & 2.0 & \text { Italy } & 0.1\end{array}$

* California and county rates, shown in blue, are mean yearly rates calculated for 1990-1995. They are somewhat less than 1980-1990 averages and are based on Department of Finance estimates rather than US census counts.

+ Country estimates are 1990-1995 averages from the World Bank's World Population Projections: 1994-95. 
cating orchards is no longer simple because there is less easily irrigated flat land.

In addition, there are no more massive irrigation projects to turn deserts into fertile plains. Finally, urban populations now wish to preserve landscape for aesthetic and recreational purposes, as well as to enhance habitat for native creatures, purposes which may not be compatible with productive agriculture.

We are not yet close to losing the state's agricultural productivity. With a $\$ 24.5$ billion farmgate value in 1996, agriculture remains a vital industry, and with $68 \%$ of its production exported (55\% to other states), agriculture is an important economic contributor to local, state and national economies.

But we are faced with the prospect of huge dislocations and management dilemmas. For instance, agricultural employment remains critical to the economies of certain regions, most notably the San Joaquin Valley, where farm-related industries directly employ $8.5 \%$ of the total employees in all economic sectors. Central Valley farmland is the target of much planned population growth. If current trends continue, almost one-third of its irrigated cropland could be urbanized by 2040 (see map, p. 20). How do we accommodate new people in agricultural areas and maintain our productivity? How do we plan and manage for a future with many more people making increasing and conflicting demands on the state's land resources?

If agriculture is to have a long-term future in this state, we must acquire a better understanding of local land-use decision-making, as well as how, when and where the state's population is growing, and its agricultural impacts. Only then can we provide researchbased information that will enable localities to make effective decisions concerning this important resource.

A.G. Medvitz, a rancher in Solano County, has an Ed.D. degree from Harvard University in Administration, Planning and Social Policy. from the urban edge where development pressures - and the benefits of the program - are greatest.

Constraints on incorporation and annexation of farmland are contained in the CorteseKnox Act and other state laws. Many policies are directly and indirectly related to land conservation, including an explicit directive to protect farmland from unwarranted conversion.

These general state policies are overseen by Local Agency Formation Commissions (LAFCOs) in each county, composed of city, county and public members. However, LAFCOs have no direct authority over land use, and cannot override city or county decisions regarding development applications. Also, LAFCOs rarely reject an annexation or incorporation proposal championed by a local community based on its impacts on farmland, and become mired in controversy when they do act to protect agricultural land.

Agriculture is typically included in the local general plan, in either the state-mandated land use or open space elements, or an optional agricultural element. However, state law does not impose any meaningful substantive requirements that local governments actually protect or preserve agricultural land in the face of development pressures. Instead, California's strong tradition of local home rule grants individual cities and counties wide discretion over land use and development decisions, which they often exercise to allow the conversion of farmland to urban uses.

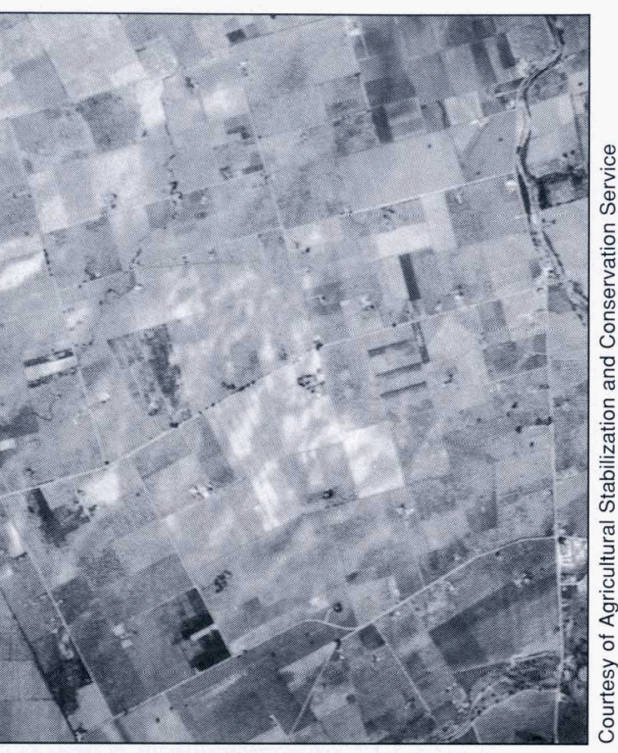

Above, Santa Clara County in 1950 is mainly fruit and nut orchards and a few row crops. Below, in 1980, the same land is covered by the rapidly growing suburbs of San Jose.

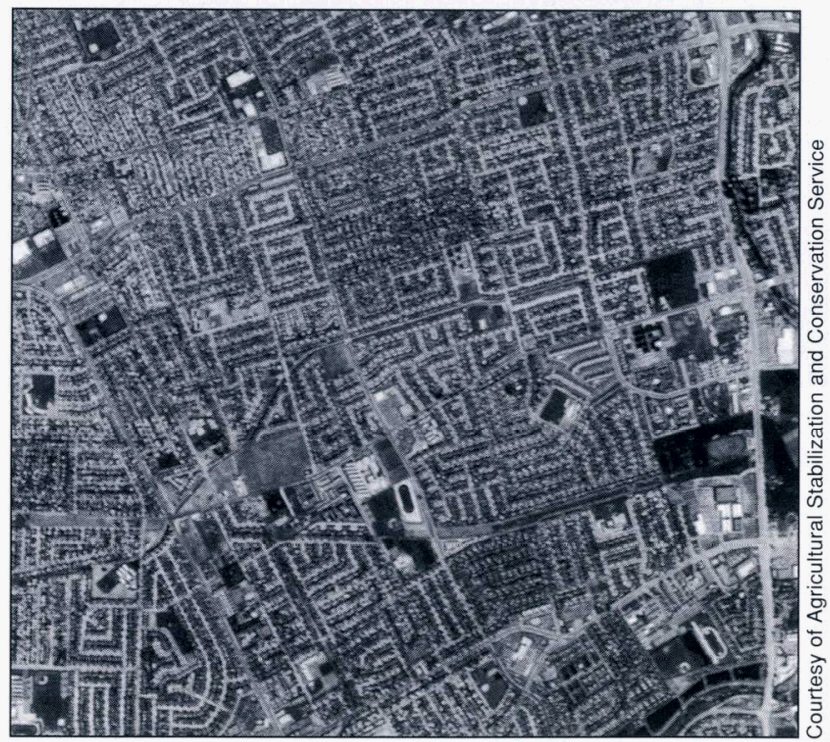

The California Environmental Quality Act (CEQA) is perhaps the preeminent state environmental statute in the nation. However, the act has several weaknesses when it comes to protecting farmland. Farmland conversion per se is not considered a "significant environmental impact" under CEQA. As a consequence, many farmland conversion actions escape environmental scrutiny altogether. Even when significantly adverse farmland impacts are identified, lead agencies are free to approve a project by making a finding that the benefits of the project outweigh the impacts, or by deciding that alternatives to the project 